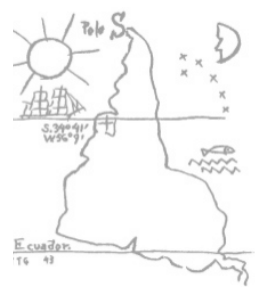

\title{
ALTERNAUTAS
}

César J. Pérez-Lizasuain

\section{Entering the Contact Zone? Between Colonialism, Neoliberal Resilience and the Possibility of Emancipatory Politics in Puerto Rico's Post-Maria}

Alternautas is a peer reviewed academic journal that publishes content related to Latin American Critical Development Thinking.

It intends to serve as a platform for testing, circulating, and debating new ideas and reflections on these topics, expanding beyond the geographical, cultural and linguistic boundaries of Latin America - Abya Yala. We hope to contribute to connecting ideas, and to provide a space for intellectual exchange and discussion for a nascent academic community of scholars, devoted to counterbalancing mainstream understandings of development.

How to cite:

Pérez-Lizasuain C. (2018), Entering the Contact Zone? Between Colonialism, Neoliberal Resilience and the Possibility of Emancipatory Politics in Puerto Rico's Post-Maria . Alternautas, 5(2), 43-55. URL:

http://www.alternautas.net/blog/2018/9/28/entering-the-contact-zonebetween-colonialism-neoliberal-resilience-and-the-possibility-of-emancipatorypolitics-in-puerto-ricos-post-maria

Editor: Alternautas

http://www.alternautas.net

London, UK.

ISSN - 2057-4924

ISSN - 2057-4924 


\section{Entering the Contact Zone? Between Colonialism, Neoliberal Resilience and the Possibility of Emancipatory Politics in Puerto Rico's Post-Maria ${ }^{2}$}

This is not a the-Island-in-a-day bus tour. This is not a tropical utopia. This is not yoga by the beach. This is not sunbathing and cabana boy service. This is not made-in-china sarongs and beaded braids. This is not an ocean clean of history. These are not fields free from memory. This is not a land unscarred by time. This is not a people of sunshine and amnesia.

This is not paradise.

Manufacturing Paradise (fragment), Ana Portnoy-Brimmer (2017)

For Boaventura de Sousa (2009) a contact zone is a social field in which different "normative life worlds meet and collide with each other." For this author, contact zones are those areas in which ideas, knowledge, forms of power, symbolic universes

' CÉSAR J. PÉREZ-LIZASUAIN is a Puerto Rican scholar. His work focuses specifically on the relationship between the normative capacity of New Social Movements, Neoliberalism and the legal system. Pérez-Lizasuain is the author of "Rebelión, no-derecho y poder estudiantil: la huelga de 2010 en la Universidad de Puerto Rico" (2018) (Rebellion, Non-law And Student's Power: The 2010 Strike At The University of Puerto Rico). He received a PhD. in Law and Society at University of Milan (Italy) and since 2011 he has served as an adjunct professor at University of Puerto Rico and as a visiting scholar at University of Massachusetts Amherst in 2018. He is currently a member of PAReS (Profesores Autoconvocados en Resistencia Solidaria), actively advocates for better working conditions for the adjunct faculty and collaborates with several media projects such as Radio Otra Podcast.

2 This article was originally published in http://www.alternautas.net/blog/2018/9/28/enteringthe-contact-zone-between-colonialism-neoliberal-resilience-and-the-possibility-of-

emancipatory-politics-in-puerto-ricos-post-maria, on September 28th, 2018.

$$
* *
$$


and rival social forces are in unequal conditions and, therefore, they mutually resist. In this paper, I conceptualize contact zone, in the context of post Hurricane Maria Puerto Rico, as a space and temporality of possible conflict and/or negotiation between social forces "in unequal power relations [...] (Sternfeld, 2017:260)." Specifically, I will argue that the linear responses ${ }^{3}$ to Hurricane Maria in the form of official policies, media and government discourses and social resistance conform a space and temporality specific to a contact zone that makes the emergence of normative sociabilities of power and resistance possible.

In what follows, I will first describe the normative life world of the colonial and neoliberal rationality. Secondly, the contact zone is completed through a response from below: the establishment of a sustainable alternative sociability based on what, drawing on the Zapatistas experience in Mexico (See Dussell, 2012) I call radical autonomy and the paradigm of the common (See also: Rivera Lugo, 2017; Laval \& Dardot, 2015; Hardt \& Negri, 2009). The interaction of those normative life worlds is a constitutive one, meaning that the antagonistic interaction between them challenges dominant political and cultural identities of the puertorriqueño.

\section{The Normative World of Colonial and Neoliberal Rationality}

Undoubtedly, the colonial and neoliberal regime in Puerto Rico precedes the scourge of Hurricane Maria on September 20, 2017. Therefore, when evaluating the "responses" that followed this atmospheric disaster, it is important to consider that the political, legal and economic base for such "answers" have been articulated from

\footnotetext{
3 The idea of response has to do with a notion of linear or progressive temporality whose logical succession of events are presented as the "natural" causes of certain social conditions. This reasoning makes use of the following narrative: "A disaster has been generated as a result of the hurricane event." This linear temporality obviates the political, economic and biopolitical conditions existing at the moment in which the atmospheric event occurs. To be more precise, the imposition of neoliberal policies of austerity during the past 15 years, before the hurricane, have made great part of the Puerto Rican population vulnerable (See Green \& Ward, 2004). The sustained winds of 150 miles per hour and the effects of Hurricane Maria have aggravated, in a decisive manner, this pre-existing condition.
} 
a long-standing colonial-neoliberal complex in the island. I'd like to identify this complex with what I call the degenerative evolution of the Commonwealth of Puerto Rico, established in 1952.

Degenerative evolution is the biological idea that states that some species can change, over time, into more "primitive" forms. By applying the analogy of degenerative evolution to ELA, I mean that the material conditions that led to the creation of this regime in 1952, along with it the populist reign of the Partido Popular Democrático, have disappeared. ${ }^{4}$

The degeneration of ELA has led the island to reconnect with its violent and openly colonial reality that remind us the early colonial period dating from the military invasion in 1898 until the establishment of ELA in 1952 in which government officials were appointed by the Congress and President of the United States. The jurisprudence of the Supreme Court of the United States in Sánchez Valle vs. ELA (579 U.S. 2016), ${ }^{5}$ and the subsequent approval of The Puerto Rico Oversight, Management, and Economic Stability Act (PROMESA) by the US Congress, which has imposed a Fiscal Control Board and a Bankruptcy Court overriding the 1952 constitution, Highlight the path of this colonial degeneration. Not in vain, in Sánchez Valle, supra, the court, by not recognizing the fundamental right to selfdetermination and the validity of Puerto Rico's Constitution, has had to take hold of the Treaty of Paris, the treaty that ended the Spanish-American war in 1898, to find the original legal source of the colonial regime.

\footnotetext{
4 The 1930s rise of the PPD, and the1952 Constitution was the result of previous social, legal, economic and political processes related to the implementation of the U.S. federal New Deal and its regulatory market economy policies in the island. The hope, driven by Munoz Marin, was that the welfare state project in Puerto Rico would bringa space of greater sovereignty based on its economic promises (Ayala and Bernabe, 2007, 102).

${ }^{5}$ In Sánchez Valle the US Supreme Court ruled that the territory of Puerto Rico is under the absolute authority of Congress so it is not recognized as a separate and autonomous sovereignty with respect to the United States.
}

** 
At the same time, we have seen a kind of evolution that has taken the form of neoliberal rationality (See Brown, 2015). In 1982, in a written article published in Foreign Affairs, the former governor of Puerto Rico Rafael Hernández Colón expressed his opposition to the Reagan's administration proposal to create the Caribbean Basin Initiative (CBI). ${ }^{6}$ The former governor complained about the lack of competitiveness that Puerto Rico would have against other independent states because "Puerto Rico must apply U.S. economic regulations and consequently does not enjoy any of the [...] freedoms"(Hernández Colón, 1982) of free nations. But Hernández Colón closes by stating that: "The commonwealth relationship possesses sufficient constitutional flexibility to allow adjustments to be made, thus allowing Puerto Rico to become a source of stability in the region (Hernández Colón, 1982)."Hernández Colón's comments were not critiques of the CBI itself, but of his rival PNP party that supported the project proposed by the Reagan administration.This marks a decisive point: from the perspective of Hernández Colón, what ELA lacks is not necessarily legal sovereignty. Instead, what was missing within the structure of ELA was its ability to adhere to the Washington Consensus. He identified, very skillfully, that the Washington Consensus represented, as Saskia Sassen (2008) has since argued, a new form of sovereignty that is no longer to be found in the nation-state but is rather found within the market forces. For him, ELA possesses sufficient constitutional flexibility to adapt neoliberalism to the local conditions. And this has, in fact, become the case, as exemplified by a series of neoliberal legal reforms, the advancement of the privatization of public assets and the imposition of austerity policies; the recent (previously mentioned) jurisprudence of both the Supreme Court of Puerto Rico and the Supreme Court of the United States; and 3 the approval of PROMESA by the U.S. Congress.

This degenerative evolution of the island's colonial regime has deepened what Wendy Brown (2006) calls a process of de-democratization, which is proper to the neoliberal and neoconservative rationality. In the case of Puerto Rico, and its post-hurricane

\footnotetext{
${ }^{6} \mathrm{CBI}$ was a kind of prototype of a free trade agreement launched in 1984. $\mathrm{CBI}$ provided trade benefits to some Caribbean nations.
} 
context, we can see this happening in three principal ways: through the privatization of public schools, public higher education, energy production (PREPA) and public lands; the establishment of new legal and Anti-labour regimes such as "Labor Transformation and Flexibility Act" of $2017^{7}$ and the well knowns Acts 20 and 22; and the conformation of authoritarian practices through the approval of "The Act for the New Government of Puerto Rico" in 2017 that was intended to amplified discretional powers to the governor of Puerto Rico (See Atiles, 2017). These legal reforms have come to promote the emergence of the so called corporate-state (Whyte, 2014) while at the same time it has legalized practices of corruption. That has been the case of hiring schemes after the hurricane. Proof of this are the questions raised by the hiring of the company White Fish Energy, a small company in Montana with just two employees that was supposed to rebuild the electric grid on the island. The amount of the contract amounts to 300 million dollars. ${ }^{9}$ Currently, the contract is subject to an audit. Ultimately, then, the degenerative evolution of the colonial regime on the one hand, the advancement and adaption of the neoliberal rationality; and on the other hand, represents an evident regression to the most basic form and definitions of colonialism.

\section{The mediatised neoliberal subject of resilience}

My invitation to you is that we take these opportunities; here in Puerto Rico we can do very well, we ask for those resources to help boost the economy, but, above all, they will help to build a stronger, more resilient and more robust Puerto Rico.

\footnotetext{
7 This legislation deregulated the labor scene in Puerto Rico. Mainly, the law facilitates the dismissal of workers without just cause, reduces productivity bonuses, considerably reduces holidays (it is accumulated half a day for a whole month of work), among other provisions.

${ }^{8}$ The acts established a series of incentives for the investment of foreign capital on the island.

9 See "Whitefish energy company halts work to restore Puerto Rico's power over unpaid bill". The Guardian. Retrieved from https://www.theguardian.com/world/2017/nov/21/whitefish-energycompany-halts-work-to-restore-puerto-ricos-power-over-unpaid-bill
} ** 
In the island, the state-corporate agenda has introduced a governmentality approach to our crisis: it has to do with a production and reproduction of narratives, symbols and meanings that tries to appeal to several cultural emblems of the puertorriqueño. In Puerto Rico we have seen the way in which important discourses on resilience and entrepreneurship have been circulating from the private and governmental sectors. This narrative comes from the biopolitical condition of the current economic and political crisis in the Island and appeals to the "common sense" that the solution to our problems resides "...in the all-encompassing framework of meanings and significations (Mavelli, 2017:497)" found in the market. Mediatic campaigns such as "Reinventarse" (reinvent yourself) from El Nuevo Día, the "Echar pa'lante" of Banco Popular, "La Isla Estrella" of the Government of Puerto Rico, among others, are examples of this narrative which seeks to create the notion that the overcoming of adversities comes from individual agencies and by reaching entrepreneurial attributes (See Martínez, 2013; Brown, 2012; Laval and Dardot, 2014).

Many of those discourses has come from mainstream media outlets in Puerto Rico and the United States. Locally, in the aftermath of Hurricane Maria, the neoliberal discourse of resilience has been best led by the mediatic propaganda of Puerto Rico se Levanta (Puerto Rico Rises Up) and Unidos por Puerto Rico (United for Puerto Rico). The latter, more than a mere narrative for 'unity', has been institutionalized as a public-private partnership created for the supply of food and basic needs promoted by Puerto Rico's first lady, Beatriz Rosselló, that has been subjected to important criticism due to inefficient management and distribution of the funds donated from abroad.

${ }^{10}$ Gobernador Rosselló Nevares invita a reconstruir a Puerto Rico más resiliente tras el paso del huracán María. (n.d.). Retrieved from http://www.fortaleza.pr.gov/content/gobernador-rossellnevares-invita-reconstruir-puerto-rico-m-s-resiliente-tras-el-paso-del

$$
* *
$$


In term of discourses, for example, last December the newspaper El Nuevo Día apparently wanted to show the economic "opportunity" that Hurricane Maria had represented for this entrepreneur man to "reinvent" his laundry business by applying resilience. Despite the government denial of more than a thousand deaths ${ }^{11}$ related to the hurricane and the lack of power for over more than six months, it seems that for El Nuevo Día, "the lack of power grid and water became an opportunity for the laundry ...". ${ }^{12}$ In another recently published piece by El Nuevo Día, entitled El duelo y el ingenio al vivir seis meses sin luz tras el huracán Maria ${ }^{13}$ [The duel and the ingenuity to live six months without energy after Hurricane Maria], an elderly couple in the Municipality of Naranjito was presented as an example of resilience and ingenuity in the face of poverty and lack of public services in the aftermath of the disaster.

Narrator: Por costumbre, despierta a las 4:00 de la mańana, abandona su cama y se ilumina con otro de sus inventos: una mecha en un frasco de aceitunas lleno gas que le sirve de lámpara. Escucha las noticias en un viejo radio que solo opera con baterías y a veces se apaga. Todavía a oscuras, calienta café en el fogón que montó utilizando cuartones y cuatro bloques de hormigón.

Man: "Esto me lo inventé yo. Aquí lavo los pantaloncillos; los tengo ahí colgando. Hago de todo
Narrator: By habit, he wakes up at $4: 00$ in the morning, leaves his bed and is enlightened by another of his inventions: a wick in a jar of olives full of gas that serves as a lamp. [I]n the dark, he heats coffee in the stove that he built using paddocks and four concrete blocks.

Man: "This I invented it myself. Here I wash my underwear; I have them hanging there. I do everything here. I cook here. Today, we are going to eat sardines."

"Since December 2017 to August 2018 the formal death toll remained at 64. Leading investigations by the New York Times and the Puerto Rican based journalist organization Centro de Periodismo Investigativo have warned of a possible scheme of concealment by the local government. , During the month of May 2018, the New England Journal of Medicine published a study stating that the total number of deaths after the passage of Hurricane Maria amounts to roughly 4,600. As recently as August 9, 2018, the Government of Puerto Rico formally raised the death toll to over 1,400 .

12 In Santiago, L. (2018). Transforma sus negocios luego del paso del huracán María. Retrieved from El Nuevo Día: http://www.magacin.com/moda/1085/transforma-sus-negocios-luego-delpaso-del-huracan-maria/

${ }^{13}$ In Guzmán, B. (2018) El duelo y el ingenio al vivir seis meses sin luz tras el huracán María. Retrieved from El Nuevo Día: https://www.elnuevodia.com/noticias/locales/nota/eldueloyelingenioalvivirseismesessinluztras elhuracanmaria-2408784/ 
aquí. Cocino aquí. Hoy lo que hay [de comer] son sardinas de lata”.

Woman: "Nos sentimos olvidados. Pero qué vamos a hacer. Que sea lo que Dios quiera [...]. Ya uno se va acostumbrando."

Man: "Quizás no es tan malo."
Women: "We feel forgotten. But what are we going to do. Let it be what God wants. " "One is getting used to it."

Man: "Maybe it's not so bad."

This image, that resembles Agamben's (2003) notion of naked life, proposes a narrative of resilience in which this new type of citizenship must assume the conditions of vulnerability as constitutive elements of normality. The neoliberal subject of resilience is supposed to prove his "...capacity to withstand the shocks of a socio-economic order (Mavelli, 2017:491)" whether the elements of vulnerability are either caused by austerity policies or by the violent scourge of a hurricane. Moreover, this subjectivity seeks to make life, under precarious conditions, a self-sustaining one in which government assistance is not necessary or even unwanted. In their analysis of Hurricane Katrina, scholars Geoffrey Whitehall and Cedric Johnson (2011:63) assert the following:

\footnotetext{
"The vulnerability created by neoliberalism is, ironically, to be solved by the very same form of citizenship it champions. Instead of citizenship taking the form of collective well-being, neoliberal citizenship is rooted in individualizing responsibility."
}

In this sense, neoliberal governmentality champions the emotion and practice of resilience through the production and reproduction of three main narratives: (1) By promoting that life without the government and public institutions is possible even in the face of an emergency (See Whitehall \& Johnson, 2011); (2) By highlighting individualistic agency, and thereby maintaining unaltered and unquestioned, the historical factors and power relations that caused the state of vulnerability; and (3) These narratives tend to legitimize, as Wendy Brown (2015) reminds us in her 
"Undoing the Demos", a violent process of de-democratization: that is, the incipient separation between demos and kratos.

The Normative Life World from Below: Community Self-Government as Resistance to Neoliberal Resilience

How, then, do we explore, question and supersede the neoliberal narrative of resilience after Hurricane Maria? For many of us the answer to this question resides in the so-called experiences of community-self government or, in the words of Mariolga Reyes-Cruz (2018), the proliferation of multiples sovereignties like Casa Pueblo in the Municipality of Adjuntas.

We create political sovereignty when we meet in assemblies and invent horizontal processes for decision-making, when we call ourselves to occupy the public sphere and fight for the common good, when we demand that those who aspire to represent us send with ear on the ground, obeying the people's best aspirations, to whom they are obliged to serve, because we only cede our sovereign power to promote the common good and not for the particular benefit of those with a direct line to their hearts or their pockets (Reyes-Cruz, 2018).

But, in many cases, the lense of neoliberal resilience also filters responses from below like community self-government or autogestión comunitaria. Chantal Mouffe (2014) argues that it is important not to lose the critical point of view in relation to the social movements that practice and proclaim autonomy; that we should not lose sight of the fact that the discourse on self-management was appropriated by post-Fordist capitalism in the 1960 's, thus developing new networks of power and control over labor. For her (2014:84), it is important that these strategies of self-management do not fall into a kind of "hegemony by neutralization". That is, the way in which many of the demands raised by these movements can be appropriated and neutralized by the predominant colonial-neoliberal complex. 
How then, to understand the political elements of autogestion in the contact zone? How can we spark the radical and political dimension of autogestion comunitaria in neoliberal Puerto Rico? Below, Iintroduce the Zapatistas' concept of radical autonomy to explore possible answers to these questions.

\section{Community Self-government and Politics: A Contrast Between Autogestión Comunitaria and the Zapatistas' Concept of Autonomy}

Autonomy for Zapatistas is the empirical institutionalization of the sociabilities performed in their conviviality (See Illich, 2011) and communal life. For them, the autonomous institutions of self-government, like the Caracoles and Juntas de Buen Gobierno, are only the outcome of previously established sociabilities. From a sociolegal perspective, Zapatista's autonomy is a normative fact (See Gurvitch, 2005) that creates a space (territory) and temporality (radical democracy) from which the "community appropriates the means of production and exchange, including land and resources, and how [they] determine the accumulation and distribution of social wealth (Rivera Lugo, 2017:124)." However, it is important to point out that radical autonomy for Zapatistas has not meant an isolation from the rest of the Mexican economic and political conflicts (Mentinis, 2006). As their name suggests, Zapatista Army of National Liberation, the Zapatistas do not abandon the national and political component in their struggle. Furthermore, in 2017 the Congreso Nacional Indigena (National Indigenous Congress) and the EZLN announced their decision to participate in the 2018 presidential elections having an indigenous woman, María de Jesús "Marichuy" Patricio Martínez, as their independent candidate (See Concheiro, 2017). On the contrary, the "project of autonomy [...] is not one of closure but of openness. It implies that a society calls into question its own institutions, its representation of the world, [and] its social imaginary (Mentinis, 2006:68)." Let's not forget that the EZLN struggle it is also the outcome of a contact zone that emerged on January 1, 1994 when two normative life worlds collided. One side of the zone represented by the rebellion and the struggle for the common; and the 
other side represented by the rationality of free enterprise promoted by the entering into effect of the North American Free Trade Agreement (NAFTA).

Taking Alain Badiou's (2013) concept of affirmative-dialectics, we could say that radical autonomy for Zapatistas have a dual quality: First, a negative one. That is, a rejection of those conditions of vulnerability that have been imposed on them for more than 500 years. This Basta! or rejection carries a dialectical charge that identify the antagonist agents in the contact zone: colonialism and neoliberalism embodied in the Mexican state or what they call el Mal Gobierno. On the other hand, the second dimension is rather an affirmative one. For Badiou, as for Holloway (2005), Dussel (2011) and Negri (2008), the logic of negativity is not enough. The affirmative dimension consists in the internal nomos or ethos of the social movement based on the paradigm of the common. Where is the common in the community? Where is the common in radical autonomy? Where is the common in autogestión?

For the Puerto Rican thinker Carlos Rivera Lugo (2017:153) the nomos of the common is characterized, on the one hand, by its denial of private property. On the other hand the nomos of the common is the empowerment of communal forms of ownership or possession, as well as of exchange and the distribution of social production. The common is inscribed as something inherent to popular sovereignty and is rooted in radical democracy or grassroots democracy (Rivera Lugo, 2017:153). The Possibility of Emancipatory Politics in Puerto Rico's Post-Maria will only occur through an antagonistic encounter between the social forces described before; that is, the colonial-neoliberal complex and the normative life world of the common. Radical autonomy comes from communities and social movements that, through political performativities (Butler \& Athanasiou, 2013), promote alternative sociabilities capable of exceeding the normative worlds of colonialism and private property.

\section{References}

Ayala, C. \& Bernabe, R. (2007) Puerto Rico in the American Century: A History since 1898. North Carolina: University of North Carolina Press. 
Atiles, J. (2017) Proyecto de ley del "Nuevo Gobierno de Puerto Rico": Estado de Excepción interno y la desposesión generalizada. Retrieved: http://lapupila.net/proyecto-deley-del-nuevo-gobierno-de-puerto-rico-estado-de-excepcion-interno-y-ladesposesion-generalizada/

Badiou, A. (2012). The rebirth of history: Times of riots and uprisings. Verso Books.

Badiou, A. (2013). Affirmative dialectics: From logic to anthropology. Badiou Studies, 2(1), $1-13$.

Brown, W. (2015). Undoing the demos: Neoliberalism's stealth revolution. MIT Press.

Butler, J., \& Athanasiou, A. (2013). Dispossession: the performative in the political. Cambridge: Polity Press.

Concheiro, L. (2017, May 28). Los pueblos indígenas de México eligen a su vocera e irrumpen en el escenario político. Retrieved from: https://www.nytimes.com/es/2017/05/28/los-pueblos-indigenas-de-mexico-eligena-su-vocera-e-irrumpen-en-el-escenario-politico/

Dussel, E. (2008). Twenty Theses on Politics. North Carolina: Duke University Press.

Gurvitch, G. (2005). La idea del derecho social: noción y sistema del derecho social, historia doctrinal desde el siglo XVII hasta el fin del siglo XIX. Granada: Editorial Comares.

Hernández-Colón, R. (1982). Puerto Rico: Partner or Victim?. Foreign Policy(47), pp. 123125.

Illich, I. (2011). La convivencialidad. México: Fondo de Cultura Económica.

Joseph, J. (2013). Resilience as embedded neoliberalism: a governmentality approach. Resilience: International Policies, Practices and Discourses, 1(1), pp. 38-52

Laval, C., \& Dardot, P. (2014). Común: Ensayo sobre la revolución en el siglo XXI. Barcelona: Editorial Gedisa.

Martínez Negrón, A. (2013). De plástico su estrella. 80 Grados. Retrieved: http://www.80grados.net/de-plastico-su-estrella/

Mavelli, L. (2017). Governing the resilience of neoliberalism through biopolitics. European Journal of International Relations, Vol. 23(3), pp. 489- 512 
Mendoza, L. (Spring 1994). The Border Between Us: Contact Zone Or Battle Zone? Modern Fiction Studies, Vol. 40, No. 1, pp. 119-139

Mouffe, C. (2014). Agonística: Pensar el mundo políticamente. Buenos Aires: Fondo de Cultura Económica.

Negri, A. (2008). La fábrica de porcelana: una nueva gramática de la política (Vol. 156). Barcelona: Ediciones Paidós Ibérica.

Portnoy-Brimmer, A. (2017). Manufacturing Paradise. Retrieved from http://lapupila.net/manufacturing-paradise/

Reyes-Cruz, M. (2018, February 2). Por quiénes esperamos. Retrieved from http://www.80grados.net/por-quienes-esperamos/

Rivera-Lugo, C. (2017). El nomos de lo común. Crítica Jurídica, Núm. 38, pp.117-148

Santos, B. (2009). Sociología Jurídica Crítica. Madrid: Editorial Trotta.

Sassen, S. (2008). Territory, authority, rights: From medieval to global assemblages. Princeton University Press.

Whyte, D. (2014). Regimes of Permission and State-Corporate Crime. State Crime Journal, Vol. 3, No. 2, State-Corporate Crime, pp. 237-246Villalba-Eguiluz, U., \& Etxanoa, I. (2017). Buen Vivir vs Development (II): The Limits of (Neo-)Extractivism. Ecological Economics, 138, 1-11. https://doi.org/10.1016/j.ecolecon.2017.03.010 